\title{
Effectiveness of Leaves Extract Fractions of Archidendron jiringa (Jack) I.C Nielsen Against Microbes
}

\author{
Oom Komala ${ }^{1 *}$, Sri Wardatun², Lia Puspita Sari ${ }^{2}$ \\ 'Department of Biology, Faculty of Mathematics and Natural Sciences, Pakuan University, Bogor, Indonesia \\ ${ }^{2}$ Department of Farmacy, Faculty of Mathematics and Natural Sciences, Pakuan University, Bogor, Indonesia
}

*Corresponding author email: oom.komala@unpak.ac.id.

Received May 31, 2019; Accepted october 10, 2019; Available online November 30, 2019

\begin{abstract}
Archidendron jiringa (Jack) I.C Nielsen) contains a lot of essential oils, saponins, alkaloids, terpenoids, steroids, tannins, glycosides, and flavonoids. Flavonoid is a secondary metabolite compound in a plant as antimicrobial. This study aims to determine the antimicrobial activity of fractions of ethanol $96 \%, \mathrm{n}$-hexan, ethyl acetate, and ethanolwater leaves extract and determine levels of favonoids. A. jiringa leaves extract were tested against Streptococus mutans, Pseudomonas aeruginosa, and Candida albicans. The research using agar disc diffusion technique for antimicrobial activity and colorimetric method to know the total of flavonoid. Chloramphenicol and ketoconazole were used as a reference standard. The result of this study shows fractions of ethanol 96\%, n-hexane, ethyl acetate, and ethanol-water A. jiringa leaves extract can inhibit microbial growth of S. mutans, P. aeruginosa, and C. albicans. Total of flavonoids on the extract respectively are $1.13 \%, 0.494 \%, 2.337 \%$, and $0.549 \%$. determined with complementary colorimetry to each leaf extract fraction A. jiringa with aluminum chloride method. Absorption spectrum measurement using a spectrophotometer. The higher percent of flavonoids would cause greater bacteria inhibitory zone but only 0.090 for pearson correlation value. Conclusions ethyl acetate leaves extract most effective inhibit microbial growth from the other fractions.
\end{abstract}

Keywords: Antimicrobial, Archidendron jiringa, Extract Fractions

\section{INTRODUCTION}

The rapid emergence of resistant bacteria is occurring worldwide, endangering the efficacy of antibiotics, which have transformed medicine and saved millions of lives (Ventola, 2015). Herbal medicine has been used especially in developing countries for many years. It is used for the traditional treatment of health problems. A. jiringa (Jack) I.C Nielsen is native to tropic countries of Southeast Asia; such as Malaysia, Bangladesh, Myanmar, South Thailand and parts of Indonesia. This plants contain protein, calcium, phosphorus, dienkolic acid (Bunawan, Dusik, Bunawan, \& Amin, 2013), vitamins $A$ and $B$, carbohydrates, essential oils, saponins, alkolids, terpenoids, steroids, tannins, and glycosides. Purified A.jiringa seed lectin have inhibitory effect against growth of plant-pathogenic bacteria and fungi (Charungchitrak, Petsom, Sangvanich, \& Karnchanatat, 2011). Flavonoids are secondary metabolites in plants as antimicrobial. Flavonoids can be used as antimicrobials because they can form complex compounds with extracellular and dissolved proteins that can damage microbial cell membranes. Xie, Yang, Tang, Chen, \& Ren (2015) explain antibacterial mechanism of flavonoid are mainly as follows : nucleic acid synthesis inhibition, alteration in cytoplasmic membrane function, energy metabolism inhibition, reduction in cell attachment and biofilm formation, inhibition of the porin on the cell membrane, changing of the membrane permeability, and attenuation of the pathogenicity. Flavonoids are large class of natural compounds, flavonoids showed up to sixfold stronger antibacterial activities than standard drugs in the market (Farhadi, Khamemeh, Iranshahi, \& Milad, 2019). Biofilm formation of Candida albicans can inhibited and disrupted by flavonoids were extracted from Moringa oleifera seed coat (Onsare and Arora, 2015). This study aims to determine antimicrobial activity and flavonoid contain of extract fraction $A$. jiringa leaves. Antimicrobial activity and flavonoid contain of extract fraction more good (Anze, Lamsing, Ugwoke, \& Ezugwu, 2017).

\section{EXPERIMENTAL SECTION \\ Extract}

A.jiringa leaves were collected from Lampung, South Sumatra. then dried, mashed and then extracted. Extract is made with cold maceration method. A. jiringa leaves powder $400 \mathrm{~g}$ is extracted by maceration. Solvent ethanol $96 \% 4000 \mathrm{~mL}$ $(1: 10)$ and leaves powder for maceration is 
protected from light at room temperature while repeatedly stirred (every 6 hours). The filtrate is filtered. Pulp of $A$. jiringa leaf added with enough solvent and stirred and then filtered again. The extract is stored in a place protected from light for 2 days, the precipitate formed separated and then filtered. The filtrate was evaporated with evaporator vacuum so get dry extract (Anonim, 2013).

\section{Fractionation of Ethanol Extract of $A$. jiringa Leaves}

The fractionation is done by Fractionation LiquidLiquid (FLL) method with $n$-hexane, ethyl acetate and ethanol solvent continuously with different solvent polarity properties. Fractionation is done (Yanti, Irnawati, Vivian, \& Wulandari, 2015) as follows: Ethanol $96 \%$ extract dissolved in water with a ratio of 1: 1 as much as $200 \mathrm{~mL}$. Subsequently incorporated into the separated flask, $200 \mathrm{ml}$ of $\mathrm{n}$-hexane was added, mixed, until separation between the $n$-hexane fraction and ethanol $96 \%$. The $n$-hexane fraction is separated, then repeated several times until clear colored. The fractionation is continued with ethyl acetate in the same process as $\mathrm{n}$-hexane. Fractions of liquid $n$-hexane, liquid ethylacetate and ethanolwater evaporated on evaporator vacuum for obtain a fraction dry extract. Next all fractions obtained were tested for antibacterial and antifungal activity.

\section{Phytochemical Test of $A$. jiringa Leaves Extract}

Phytochemical test were conducted qualitatively on A. jiringa leaves extract to determine the presence of flavonoids, saponins, tannins, and alkaloids in extracts that may act as antimicrobials. Test for flavonoids, take some petroleum ether extract in a test tube then add magnesium ribbon powder and a few drops of $5 \mathrm{M}$ hydrochloric acid showing red to purple indicating there are flavonoid compounds. Test for saponins, take all the four extracts separately in test tubes and add water into them and shake strongly, if the formation of solid foam for not less than 10 minutes, as high as $1-10 \mathrm{~cm}$. Add 1 drop of $2 \mathrm{~N}$ hydrochloric acid, the foam does not disappear indicate the presence of saponin compounds. Test for tannins, the filtrate was evaporated furthermore add hot distilled water and stirred. After cold centrifuging, the liquid above is separated by decantation and the solution is tested. Add 10\% gelatin or $\mathrm{NaCl}$-gelatin $(1: 1)$ white sediment will arise, or added with a solution of $3 \%$ ferric (III) chloride will occur in a green blue color until blackness indicates the presence of tannin compounds. Test for Alkaloids, take some petroleum ether extract of $A$. jiringa leaf in a test tube and add 2-3 drops of Dragendroffs reagent (potassium bismuth iodide solution) appearance of pale yellow colour indicates that absence of alkaloids in this extract. Again perform the same experiment with chloroform, methanol and water extract in another test tube appearace of pink colour indicates that absence of alkaloids in these extract. Appearance of brown colour indicates that presence of alkaloids (Gupta, Thakur, Sharma, \& Gupta, 2013). Flavonoid total was determined used complementary colorimetry for each fractions of leaves extract with UV-Vis spectrophotometer (Ramos, Bezerra by alumunium chloride method. The maximum absorbance of quercetin measured at wavelength $380-780$ nm, Ferreira, \& Soares, 2017).

\section{Antimicrobial Test \\ Minimum Inhibitory Concentration (MIC)}

Minimum Inhibitory Concentration by using agar dilution technique against microorganism. The concentration of extract were made 50, 100, 200, and $400 \mathrm{mg} / \mathrm{mL}$. Sterile media included in each petri dish $20 \mathrm{~mL}$. Each petri dish was inserted $1 \mathrm{~mL}$ of extract concentration, $0.2 \mathrm{~mL}$ of microbial suspension 0.5 Mc Farland then homogenized and allowed to harden (Mazzola, Jozala, Novaes, Moriel, P.\& Penna, 2009). Incubated for 24 hours at $37^{\circ} \mathrm{C}$, and see the growth bacteria and fungi. The lowest concentration of antimicrobials that do not occur microbial growth in petri dishes was the Minimum Inhibitory Concentration (MIC).

\section{Antimicrobial effectiveness test and Experimental Design}

Testing the effectiveness of $A$. jiringa leaves extract by using agar disc diffusion technique. In this method are seen the clear zones around the paper disc. Total of $0.2 \mathrm{~mL}$ bacterial inoculum of $10^{6}$ cell $/ \mathrm{mL}$ and mushrooms inoculum of $10^{4} \mathrm{cell} / \mathrm{mL}$ were added into petri dishes containing $20 \mathrm{~mL}$ of nutrient agar for bacteria and sabouraud dectrosa agar (SDA) medium for C. albicans then homogenized and allowed solid in separate petri dishes. Paper disc containing A. jiringa leaves extract, chloramphenicol $10 \mathrm{ppm}$ and ketoconazole $50 \mathrm{ppm}$ as a reference standard were placed on nutrient agar and SDA medium. Petri dishes containing bacteria and fungi were sealed and incubated in at $37^{\circ} \mathrm{C}$. It was observed and measured the diameter of the inhibitory zone using a ruler after 24 hours incubation (Balouiri, Sadiki, \& Ibnsouda, 2016). This experiment used Factorial Randomized complete design $4 \times 2 \times 2$.

\section{Data analysis}

Data of Inhibitory zone used Analysis of Variance (ANOVA) with Factorial Randomized Complete Design (RAL) pattern using SPSS 17 with 4 treatment (3 treatment) with various concentration of A. jiringa leaves extract, 1 treatment chloramphenicol $10 \mathrm{ppm}$ or ketoconazole $50 \mathrm{ppm}$ were used as a reference standard, is repeated 2 times. The analysis was continued by Duncan test to compare the antimicrobial power between each treatment. 


\section{RESULTS AND DISCUSSION}

400 grams of $A$. jiringa leaves powder dissolved in 4 liters of ethanol $96 \%$ solvent. Dry extract obtained as much as $100.1 \mathrm{~g}$. The extract is fractionated stepwise with the aim of simplifying the extracted secondary metabolite compound. Fractionation is done based on the nature of polarity. The fractionation process is used with 3 different solvents $n$-hexane, ethyl acetate, and ethanol-water. The use of solvents during the fractionation process is intended to get secondary metabolite compounds such as oil to completely separate or dissolve the fat contained in the extract. The fractionation is continued by using an ethyl acetate solvent to attract all semi-polar secondary metabolite compounds, i.e flavonoids, alkaloids, tannins and saponins compounds.

The final fractionation using a ethanol-water solvent is intended to attract polar compounds, i.e flavonoids, alkaloids, tannins and saponins compounds. The three fractions obtained were evaporated to get dry extract.

\section{Results of Phytochemical test}

The results of phytochemical tests showed that $A$. jiringa leaves contains saponins, flavonoids, tannins and alkaloids compounds. These simplicia results are consistent with the results of phytochemical screening of A. jiringa leaves by Hussin, Osman, Harun, \& Daud (2018). n-hexane extract are not have flavonoids, tannins and saponins. At the fraction of n-hexsan only alkaloids. There were possible alkaloids was non polar so that it is more soluble in $\mathrm{n}$-hexsan. Flavonoids, saponins, tannins are polar compounds so they are more soluble in polar solvents such as ethanol. Phytochemical test results can be seen in Table 1.

\section{Results of flavonoids Total}

Flavonoids content is in ethanol $96 \%$ extract is $1.13 \%$, in $n$-hexane fractions extract is $0.494 \%$, in ethyl acetate extract is $2.337 \%$, and ethanol-water extract is $0.549 \%$. Flavonoid flavones and flavonols are more easily soluble in semipolar solvents so that the total flavonoid content in the ethyl acetate extract is greater (Ramos et al., 2017). Farhadi et al. (2019) argued total flavonoid affect the strongest of antibacterial activity. The greater total flavonoid content be effect the higher the antibacterial activity. The results can be seen in Table 2 .

\section{Minimum Inhibitory Concentrations}

Minimum Inhibitory Concentrations (MIC) leaves extract of A. jiringa can be seen in Table 3. Extract of $n$-hexane fractions did not inhibit to $P$. aeruginosa, S. mutans and C. albicans fungus. Possibly because the alkaloids are in n-hexane too little. According to Pervaiz, Khan, \& Amin (2019) alkaloid acts as an emerging therapy for bacterial infections by inhibiting a broad range of gram positive and gram negative bacteria that were mostly resistant to current therapies. It was concluded that these alkaloids could be useful and effective therapeutic alternative to existing therapies that are extensively facing challenges of resistance. Thus, it could be expected that plant alkaloids will be the popular drugs of future. Research results Hamdani, Ansari, Fdil, Abbouyi, \& Khyari, (2016) show that the alkaloids extracts from seeds and flowers were inactive against all microorganisms tested (C.albicans, C. tropicalis and Aspergillus niger).

A. jiringa leaves extract ethanol 96\%, ethyl acetate fractions and ethanol-water fractions can inhibit microbes. Ethyl acetate fractions in this study was very weak in inhibiting C. albicans MIC occurs at $40 \%$. MIC of fractions different for each microbe. Leaves, pods and seeds of $P$. jiringa were extracted using methanol showed the antimicrobial and antifungal activities against the test organisms (Yanti et al., 2015).

Table 1. Phytochemical Results of A. jiringa Leaves Extract

\begin{tabular}{lccccc}
\hline $\begin{array}{l}\text { Identification of } \\
\text { Compounds }\end{array}$ & Simplicia & $\begin{array}{c}\text { Sample } \\
\text { ethanol } 96 \%\end{array}$ & $\begin{array}{c}\text { n-hexane } \\
\text { extract }\end{array}$ & $\begin{array}{c}\text { ethyl acetate } \\
\text { extract }\end{array}$ & $\begin{array}{c}\text { ethanol-water } \\
\text { extract }\end{array}$ \\
\hline flavonoids & + & + & - & + & + \\
alkaloids & + & + & + & + & + \\
tannins & + & + & - & + & + \\
saponins & + & + & - & + & + \\
\hline
\end{tabular}

Note: $(+)=$ There are compounds $(-)=$ there are not compounds

Table 2. Percentage of Total Flavonoid of A. jiringa Leaves Extract

\begin{tabular}{lc}
\hline Extract & Total Flavono \\
\hline Ethanol $96 \%$ & 1.13 \\
n-hexane fractions & 0.494 \\
Ethyl acetate fractions & 2.337 \\
Ethanol-water fractions & 0.549 \\
\hline
\end{tabular}


Table 3. Minimum Inhibitory Concentrations of Leaves Extract Fractions of Archidendron jiringa

\begin{tabular}{llcc}
\hline Microbes & Extract & MIC $(\%)$ & MIC $(\mathrm{mg} / \mathrm{mL})$ \\
\hline P. aeruginosa & Ethanol 96\% & 10 & 100 \\
& n-hexane fractions & - & - \\
& Ethyl acetate fractions & 5 & 50 \\
\multirow{5}{*}{ S.mutans } & Ethanol-water fractions & 5 & 50 \\
& Ethanol 96\% & 20 & 200 \\
& n-hexane fractions & - & - \\
& Ethyl acetate fractions & 20 & 200 \\
C. albicans & Ethanol-water fractions & 5 & 50 \\
& Ethanol 96\% & 5 & 50 \\
& n-hexane fractions & - & - \\
& Ethyl acetate fractions & 40 & 400 \\
& Ethanol-water fractions & 5 & 50 \\
\hline
\end{tabular}

Note : - not inhibit

Table 4. Diameter of Inhibition zone A. jiringa Leaves Extract $(\mathrm{mm})$ against $P$. aeruginosa, S. mutans and C. albicans

\begin{tabular}{|c|c|c|c|c|c|}
\hline \multirow[t]{2}{*}{ Extract } & \multirow[t]{2}{*}{ Microbes } & \multicolumn{3}{|c|}{ Concentration } & \multirow{2}{*}{$\begin{array}{c}\text { Chloram Phenicol/Ketoconazole } \\
\text { (reference standard) }\end{array}$} \\
\hline & & $50 \mathrm{mg} / \mathrm{mL}$ & $100 \mathrm{mg} / \mathrm{mL}$ & $200 \mathrm{mg} / \mathrm{mL}$ & \\
\hline \multirow[t]{3}{*}{ Ethanol 96\% } & P. aeruginosa & $7 \pm 0.02^{f}$ & $8 \pm 0.02^{\mathrm{e}}$ & $9.5 \pm 0.02^{c d}$ & $30 \pm 0.02^{b}$ \\
\hline & S. mutans & $8 \pm 0.01^{e}$ & $9 \pm 0.01^{d}$ & $10 \pm 0.02^{c}$ & $30 \pm 0.02^{b}$ \\
\hline & C. albicans & $7.5 \pm 0.02^{\mathrm{ef}}$ & $9 \pm 0.02^{d}$ & $11 \pm 0.01^{\mathrm{b}}$ & $30 \pm 0.03^{b}$ \\
\hline \multirow[t]{3}{*}{ Ethyl acetate } & P. aeruginosa & $8 \pm 0.02^{g}$ & $9 \pm 0.03^{f}$ & $10 \pm 0.03^{e}$ & $32 \pm 0.02^{a}$ \\
\hline & S. mutans & $9 \pm 0.02^{f}$ & $10 \pm 0.02^{\mathrm{e}}$ & $12 \pm 0.02^{d}$ & $31.5 \pm 0.02^{b}$ \\
\hline & C. albicans & $8 \pm 0.01^{g}$ & $9 \pm 0.02^{f}$ & $12 \pm 0.02^{d}$ & $30 \pm 0.03^{b}$ \\
\hline \multirow{3}{*}{$\begin{array}{l}\text { Ethanol- } \\
\text { water }\end{array}$} & P. aeruginosa & $7 \pm 0.02^{e}$ & $8 \pm 0.03^{\text {de }}$ & $9 \pm 0.01^{\mathrm{de}}$ & $27.5 \pm 0.02^{b}$ \\
\hline & S. mutans & $7.5 \pm 0.01^{\mathrm{de}}$ & $8.5 \pm 0.02^{\mathrm{de}}$ & $10 \pm 0.02^{d}$ & $30 \pm 0.02^{b}$ \\
\hline & C. albicans & $7 \pm 0.01^{\mathrm{e}}$ & $9 \pm 0.02^{\mathrm{de}}$ & $10 \pm 0.02^{d}$ & $25 \pm 0.02^{b}$ \\
\hline
\end{tabular}

Note : Reference standard: Chloramphenicol for P. aeruginosa and S. mutans, Ketoconazole for C. Albicans

\section{Diameter of Inhibition zone}

Concentration of 50,100 , and $200 \mathrm{mg} / \mathrm{mL}$ fractions of $A$. jiringa leaves extract and Chloramphenicol/ Ketoconazole have significant effect on microbial growth. Fractions of $A$. jiringa leaves extract have different effects in inhibiting microbial growth of $P$. aeruginosa, $S$. mutans and $C$. albicans (Table 4 \& Figure 1). As for the interaction between the concentration and microbes obtained that ethyl acetate extract concentration of 50, 100, and $200 \mathrm{mg} / \mathrm{mL}$ have different effect from control $(+)$ in inhibiting microbial growth.

Result of the research show that the concentration of 50,100 , and $200 \mathrm{mg} / \mathrm{mL}$ ethanol $96 \%$, ethyl acetate and etanol-water extract did not give the same effect with reference standard for inhibit of microbial growth. A. jiringa leaves extracts have antibacterial on $P$. aeruginosa and $S$. mutans, antifungal on $C$. albicans. Reference standard is best in inhibiting microbes. Peng, et al (2015) explains that the extract can damage the cell through the cell wall of the bacteria that the cell membrane is destroyed, irregular cell forms, the longer severely damaged cells, there is a loss of cell integrity and the cytoplasmic leaking out of the cell, the shape of the cell becomes more irregular. According to Raut, Shinde, Chanhan, \& Karuppayil (2013) that plant terpenoids inhibit morphogenesis, adhesion and formation of biofilms by C. albicans. Minimum inhibitory consentration in previous research showed that the leaves extract of $A$. jiringa was most active against $S$. aureus, $S$. epidermidis and Microsporum gypseum $\quad(100 \mathrm{mg} / \mathrm{mL})$ (Bakar, Ahmad, \& Sulaiman, 2012). The results of this study with ethanol-water fraction can inhibit $P$. aeruginosa, $S$. mutans and C. albicans $\mathrm{MIC}$ at $50 \mathrm{mg} / \mathrm{mL}$. A. jiringa leaves extract fraction which showed the widest inhibited is fraksions of ethyl acetate against $S$. mutans. This is because flavonoids compounds contained in the extract. Flavonoids are a group of phenols that have a tendency to bind microbial proteins and interfere with protein metabolism. Hydroxy groups present in flavonoids cause changes in organic components and nutrient transport which cause toxic effects on microbes. Tannins, flavonoids, terpenoids and saponin were the main secondary metabolites found in phytochemical screenings from P. jiringa stem bark (Hussin et al., 2018). Terpenoids tested (linalool, benzyl benzoate, eugenol, citral, linalyl acetate and citronellal) exhibited excellent activity against $C$. albicans yeast and hyphal form growth at the concentrations that are non toxic to HeLa cells at $\leq 0.064 \%(\mathrm{v} / \mathrm{v})$ (Zore, Thakre, Jadhad, \& Karuppayil, 2011). 


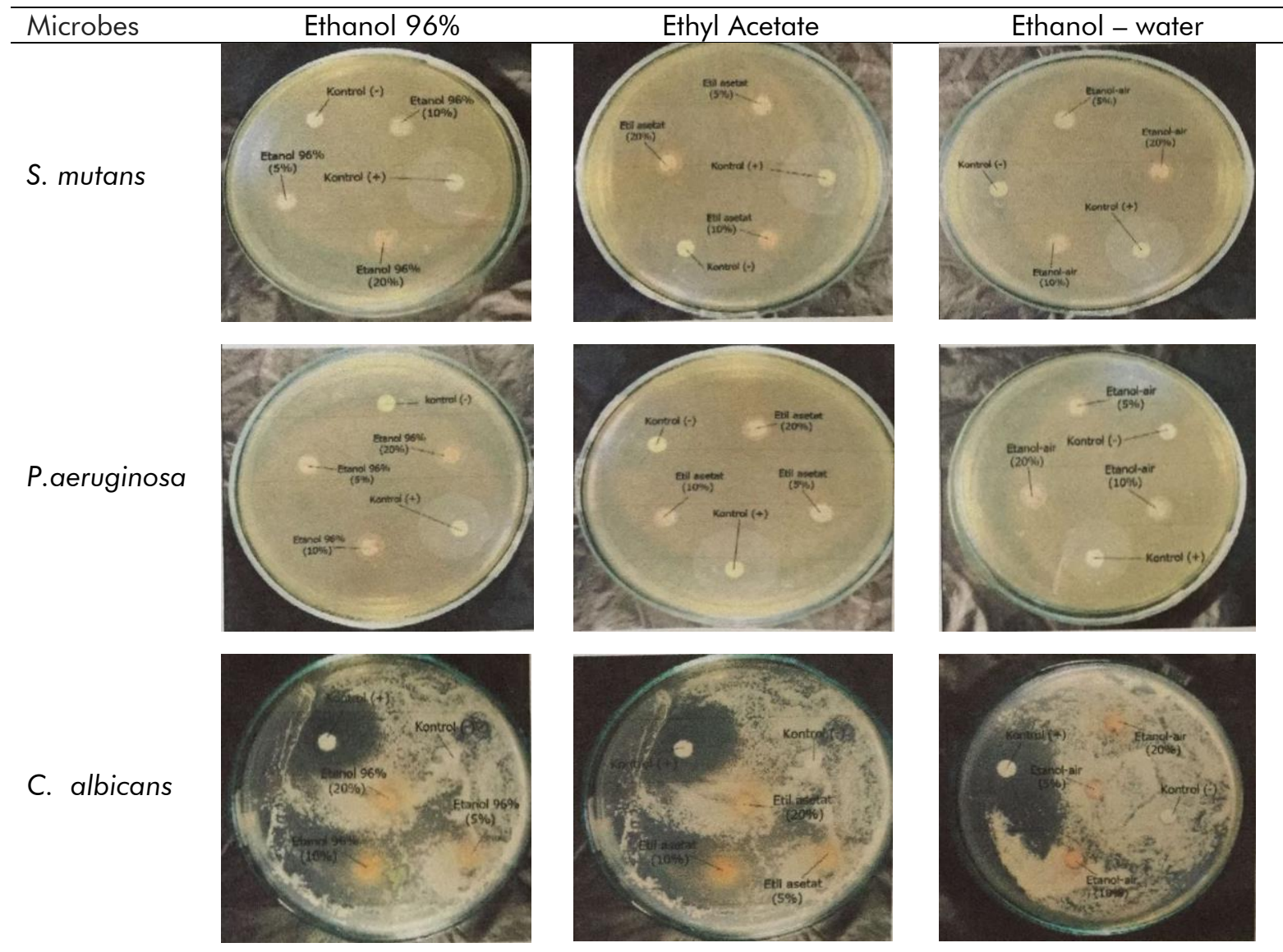

Figure 1. Inhibition Zone of A. jiringa (Jack) I.C Nielsen Leaves Extract Based on Difference of Fractions Against Microbe

Effect of $A$. jiringa pericarp extract (inhibition zone $=13.35 \pm 0.45 \mathrm{~mm}$ ) showed the highest growth inhibitory against E.coli and $S$. aureus. Extract of $A$. jiringa pericarp were contributed tentatively from flavonoids glycoside and proanthocyanidins (Ramli, 2013). There were not correlation between the total flavonoid with the size of the inhibitory diameter in this research using pearson correlation method from 72 analyzed data. The value of significance (sig (2tailed) was 0.454 ( $p>0.05)$. Retrieved a correlation value of 0.090 between the total flavonoid with the size of the inhibitory diameter. Based on these results that antimicrobial activity is only $9 \%$ influenced by the content of flavonoids while the remaining $91 \%$ is the contribution of other compounds that also have the potential as an antimicrobial.

Results of analysis chromatography time of flight mass spectrometry dienkolic acid has been found in A. jiringa bean. Norulaini et.al. (2011) reported on the volatile oil $A$. jiringa seeds using supercritical carbon dioxide with fast gas chromatography time of flight mass spectrometry revealed 55 metabolites. Pods of $A$. jiringa contain active phenolic compound as methyl gallate that has high antioxidant activity (Lubis, Marpaung, Siburian, \& Nasution, 2018). The metabolites identified were generally found to be fatty acids, terpenoids, ally sulphur, vitamin E and alkaloids. In the disc paper diffusion method, extracts of A. jiringa pericarp make inhibitory zone $=13.35 \pm 0.45 \mathrm{~mm}$ showed the highest growth inhibitory againt $S$. aureus. Extracts of $A$. jiringa pericarp showed the highest inhibitory in the in vitro to tyrosinase enzyme inhibitory property with LTyrosine as substrates. The biological activities of A. jiringa pericarp ethanolic extracts was contributed by the tentatively characterized flavonoids glycoside and proantocyanidins from the extracts. Pods examination of $A$. jiringa afforded tree proantocyanidins known as procyanidinds B-3 and B4 and prodelphinidin B-1, as well as flavan 3-ols. Proanthocyanidins have a good inhibitory effect against some isolate except high concentrations $500 \mathrm{mg} / \mathrm{mL}$ to $E$. coli and Salmonella typhimurium was more inhibitory activity (Hasan, 2013). Results in research, extract of A. jiringa leaves ethanol 96\%, ethyl acetate fractions and ethanol-water fractions can inhibit microbes. Fraction can strengthen inhibition.

\section{CONCLUSIONS}

A. jiringa leaves fractions can inhibit the growth of S. mutans, P. aeruginosa, and C. albicans. Fractions of ethyl acetate leaves most effective than the ethanol $96 \%$ and ethanol-water fractions. 


\section{ACKNOWLEDGEMENTS}

Thank to the Pharmacy Laboratory, Faculty of Mathematics and Natural Sciences, Pakuan University and Bogor Agricultural University.

\section{REFERENCES}

Anonim. (2013). Farmakope Herbal Indonesia, First Ed. Dep. Of Health RI, Indonesia: Jakarta, pp106-107.

Anze, S.P.G., Lamsing, N., Ugwoke, C.E.C., \& Ezugwu, C.O. (2017). Antimicrobial Activity of Methanol Extracts and Fractions of the Leaf and Stem Bark of Vitex Doniana Sweet (Lamiaceae). International Journal of Physical and Human Geography, 5(1),14-21.

Bakar RA, Ahmad, I., \& Sulaiman, S.F. (2012). Effect of Pithecellobium jiringa as antimicrobial agen. Bangladesh Journal of Pharmacology, 7(2), 131-134.

Balouiri,M., Sadiki,M., \& Ibnsouda, S.K. (2016). Methods in vitro evaluating antimicrobial activity : A review. Journal of Pharmaceutical Analysis, 6(2),71-79.

Bunawan, H., Dusik, L., Bunawan. S.N., \& Amin, M.N. (2013). Botany, Traditional Uses, Phytochemistry and Pharmacology of Archidendron jiringa: A Review. Global J. Pharmacol, 7 (4), 474-478.

Charungchitrak, S., Petsom, A., Sangranich,P., \& Karnchanatat, A. (2011). Antifungal and antibacterial activities of lectin from the seeds of Archidendron jiringa Nielsen. Food Chemistry, 126(3), 1025-1032.

Farhadi, F., Khamemeh, B., Iranshahi, M., \& Milad I. (2019). Antibacterial activity of flavonoids and their structure-activity relationship : An update review. Phytotherapy Research, 33, 13-40. Doi : 10.1002/ptr.6208

Gupta, M., Thakur, S., Sharma, A., \& Gupta, S. (2013). Qualitative and Quantitative Analysis of Phytochemicals and Pharmacological Value of Some Dye Yielding Medicinal Plants. Oriental Journal of Chemistry, 29(2), 475-481. Doi : 10.13005/OJC/290211

Hamdani, N.E., Ansari, N.F., Fdil, R., Abbouyi, A.E., \& Khyari, S.E. (2016) Antifungal activity of the alkaloids extracts from aerial parts of Retama monosperma. RJPBCS, 7(2),965-971.

Hasan, A.M. (2013). In-Vitro Antibacterial Activity Of Proanthocyanidins Against some of Pathogenic Bacterial Isolates. Al-Mustansiriyah J.Sci.,

24(1),53-60

Hussin, Z.M., Osman, N.A., Harun, A., \& Daud S. (2018). Phytochemical and Antimicrobial Evaluation of Pithecellobium jiringa Stem Bark Extracts. Malaysian Journal of Analytical Sciences, 22(1), 123-127. Doi: https://doi.org/10.17576/mjas-2018-220-15
Lubis, M.Y., Marpaung, L., Siburian, R., \& Nasution, M.P. (2018). Methyl Gallate from Jiringa (Archidendron jiringa) and Antioxidant Activity. Asian Journal of Pharmaceutical and Clinical Research, 11(1), 346.

Mazzola, P.G., Jozala, A.F., Novaes, L.C.L., Moriel, P. \& Penna, T.C.V. (2009). Minimal inhibitory concentration (MIC) determination of disinfectant and/or sterilizing agents. BJPS, 45(2), 241-248. www.scielo.br/pdf/ bjps/v45n2/v45n2a08.pdf

Norulaini, N.A.N., Zaidul, I.S.M., Azizi, C.Y.M., Zhari, I., Noranin, M.N., Sahena, F., \& Omar, A.K.M. (2011). Supercritical Carbon dioxide fractionation of Pithecellobium jiringa Jack seed compositions using fast gas chomatography time of flight mass spectrometry. Journal of food Process Engineering, 34(5), 1746-1758.

Onsare, J.G., \& Arora, D.S. (2015). Antibiofilm potential of flavonoids extracted from Moringa oleifera seed coat against Staphylococcus aureus, Pseudomonas aeruginosa and Candida albicans. J Appl Microbiol, 118(2), 313-25.

Peng, L., Kang, S., Yin, Z., Jia, R., Song, X., Li, L, Li, Z., Zou, Y., Liang, X., Li, L., He, C., Ye, G., Yin, L., Shi, F., Lv, C., Jing, B. (2015). Antibacterial activity and mechanisms of berberine against Streptococcus agalactiae. Int J Clin Exp Pathol, 8(5),5217-5223

Pervaiz, A., Khan, H., \& Amin, S. ( 2019). Therapeutic Potential of Alkaloids as AntiBacterial Agents: Drugs of Future. Current Bioactive Compounds, 15(1), 31-40. Doi: 10.2174/1573407213666170221153319

Ramli, S. (2013). Bioactivity evaluations and phytochemical characterizations of ethanolic extracts from selected mimosaceous plants endemic to Thailand. Global Journal of Pharmacology, 7 (4), 474-478.

Ramos, R.T.M., Bezerra, I.C.F., Ferreira, M.R.A., \& Soares, L.A.L. (2017). Spectrophotometric Quantification of Flavonoids in Herbal Material, Crude Extract, and Fractions from Leaves of Eugenia uniflora Linn. Pharmacognosy Research, 9(3), 253-260. https://pdfs.semanticscholar.org/7640/43709 ca51c6f6b218ele9f70084745583004.pdf

Raut, J.S., Shinde, R.B., Chanhan, N.M., \& Karuppayil, S.M. (2013). Terpenoids of plant origin inhibit morphogenesis, adhesion, and biofilm formation by Candida albicans. Biofouling, 29(1) : 87-96. doi: $10.1080 / 08927014.2012 .749398$

Ventola, C.L. (2015). The Antibiotic Resistance Crisis. Part 1 : Causes and Threats. PT, 40(4), 277283.

Xie ,Y, Yang W, Tang, Chen X \& Ren I. (2015). Antibacterial activities of flavonoids: structure - 
Molekul, Vol. 14. No. 2, November 2019: 110 - 116

activity relationship and mechanism. Current Medicinal Chemistry, 22(1), 132-149.

Yanti, Irnawati, F., Vivian, M., \& Wulandari, Y.R.E. (2015). Extraction yield and antioxidant activity of biomolecule and bioactive fractions from seed and peel parts of Pithecellobium jiringa. Sch.Acad J.Biosci., 3(9), 790-795
Zore, G.B., Thakre, A.D., Jadhad, S., \& Karuppayil, S.M. (2011). Terpenoids inhibit Candida albicans growth by affecting membrane integrity and arrest of Cell Cycle. Phytomedicine, 18(13), 1181-90. 